\section{Barley Mutants}

T. Lawrence (Canad. J. Bot., 33, 6, 515; 1955) has described the production of mutations by irradiating Montcalm barley in different ways. Five radiation sources were used for inducing mutations in barley, all treatments being given at a dosage of $10,000 \mathrm{r}$. equivalent. The radiation sources with their respective dose-rates in the region of the irradiated seeds were : a betatron (181.8 r./min.), an X-ray machine (201 r./min.), radium-beryllium $(5 \cdot 3 \mathrm{r} . / \mathrm{min}$.$) , and$ two cobalt-60 sources $(4 \cdot 5 \mathrm{r} . / \mathrm{min}$. and $75 \cdot 75 \mathrm{r}$. $/ \mathrm{min}$.). None of the radiation sources used was more effective than the X-ray treatment in producing mutations. The betatron and the high dose-rate treatments from cobalt-60 appear to be somewhat less effective than X-rays. More than thirty different mutant types were produced, including a number of vital mutants, such as stiff-strawed and early-maturing types. These appear promising as new varieties, but require further agronomic evaluation.

\section{University of Birmingham : Appointments}

Dr. N. A. DudLEx, lecturer in engineering production in the University of Birmingham, has been appointed reader in engineering production and head of the Department of Engineering Production for a period of three years. The following have been appointed to lectureships in the University: T. K. Chaplin (civil engineering), Dr. T. B. Massalski (physical metallurgy), R. B. Hoole (mining) and Dr. J. N. Hawthorne (pharmacology). The following members of staff of the National Vegetable Research Station, Wellesbourne, have been appointed recognized lecturers in the University : D. W. Wright (attached to the Department of Zoology) and Dr. W. G. Keyworth (attached to the Department of Botany).

\section{Royal Institution : Officers}

THE following have been elected officers of the Royal Institution: President, Lord Brabazon of Tara; Treasurer, Mr. W. E. Schall ; Secretary, Mr. S. Robson; Managers, Dr. T. E. Allibone, Mr. E. R. Davies, Sir Alfred Egerton, Dr. A. G. Gaydon, Mrs. H. K. Hawkes, Brigadier H. E. Hopthrow, Mr. L. B. W. Jolley, Dr. H. Lowery, Mr. J. A. Oriel Prof. H. J. Plenderleith, Dr. J. H. Schulman, Mr. P. H. Schwarzschild, Dr. R. Seligman, Dr. C. Keith Simpson and Prof. W. D. Wright ; Visitors, Lieut.Colonel S. J. M. Auld, Mr. F. G. Brown, Mr. R. C. Chirnside, Dr. F. H. Cotton, Mr. H. W. Cremer, Miss E. H. Jebens, Dame Kathleen Lonsdale, Mr. G. Parr, Mr. J. D. Peattie, Dr. R. Scott Russell, Miss Daphne Sidebottom, Dr. P. C. Spensley, Mr. W. R. Stevens, Mr. S. A. Stigant and Dr. D. T. A. Townend.

\section{Institute of Petroleum : Officers}

THE following have been elected officers of the Institute of Petroleum for 1956-57 : President, Rt. Hon. Lord Geddes ; Past-Presidents, Lieut.-Colonel S. J. M. Auld, T. Dewhurst, Dr. A. E. Dunstan, E. A. Evans, Prof. F. H. Garner, H. S. Gibson and C. A. P. Southwell; Vice-Presidents, Dr. E. B. Evans, A. C. Hartley, E. LeQ. Herbert, R. B. Southall and E. J. Sturgess; Honorary Treasurer, G. H. Coxon ; Honorary Secretary, C. Chilvers; General Secretary, D. A. Hough; Editor, George Sell ; New Member of Council, M. E. Hubbard.

Annual Meeting of the Society of Chemical Industry

Is addition to the lectures to be given at the seventy-fifth annual meeting of the Society of
Chemical Industry during July 9-15 (see Nature, March 31, p. 609), a number of visits will be made to factories and research organizations in the London area. They include the Paint Research Station at Teddington, the National Institute for Medical Research, the Central Electricity Authority (Bankside Generating Station), Glaxo Laboratories, the Isle of Grain refinery of Shell-Mex and B.P., and the Atomic Energy Research Establishment at Harwell. The meeting begins with a reception on the Monday evening at Guildhall by the chairman, Sir Charles Dodds, and Lady Dodds, and the annual general meeting will take place the next day. The annual dinner will be held on the Wednesday at the Dorchester Hotel.

\section{South-Eastern Union of Scientific Societies: Congress in Tunbridge Wells}

THe sixty-first congress of the South-Eastern Union of Scientific Societies will be held during May 24-27 in Tunbridge Wells, the town where the Union first met in 1896. The president-elect is Dr. W. E. Swinton, chief scientific officer of the British Museum (Natural History), whose address, "Nature and the Free Mind", will be given on May 25. In the various sections of the Union, addresses will be given by the following: Archoeology, Major J. M. 'T. Burchell (the archæology of the Medway Estuary) ; Botany, Prof. C. T. Ingold (Gasteromycetes or Nature tries again); Geology, C. Fagg (swallow holes in the Mole Gap), and Prof. S. W. Wooldridge (geomorphology of the central Weald); and Zoology, Prof. H. R. Hewer (the importance of keeping field records). Further information can be obtained from the honorary local secretary, Mrs. H. Vernede, Carlton House, Carlton Road, Tunbridge Wells, Kent.

\section{Tenth International Congress of Entomology, Montreal}

THE Tenth International Congress of Entomology will be held in Montreal during August 17-25, the meetings being at McGill University and the University of Montreal. The sections of the Congress have been arranged provisionally as follows: systematics, morphology and anatomy, physiology, behaviour, ecology, geographical distribution, genetics and biometries, palæontology, arachnids and other land arthropods, agricultural entomology, forest entomology, medical and veterinary entomology, entomology of stored products, biological control, and apiculture. A visit to the Science Service Laboratories, Ottawa, and a number of short excursions will be made during the Congress, following which tours to a number of more distant laboratories and excursions for collecting will be arranged. Further information can be obtained from the secretary of the Congress, J. A. Downes, Division of Entomology, Science Service Building, Ottawa, Ontario.

\section{Third International Congress on High-speed Photography}

THE third international congress on high-speed photography will be held in the Government Offices, Horse Guards Avenue, London, S.W.1, during September 10-15, and is being sponsored by the Department of Scientific and Industrial Research. The following main topies will be considered: flash sources for high-speed photography and high-speed cinematography; mechanical-optical cameras and drum cameras; high-speed shutters, and scanning 